Dept. Food Hygiene (Meat Hygiene)

Fac. Vet. Med., Assiut University.

\title{
LEVELS OF LEAD AND CADMIUM IN SOME MEAT- PRODUCTS SOLD IN ASSIUT CITY, EGYPT
}

\author{
(With 3 Tables)
}

\section{By}

\author{
SH.M.S. ABD-ALLAH and Z.M. ZAKY*
}

* Dept. Forensic Med. and Toxicology, Fac. Vet. Med., Assiut University

(Received at 16/9/2011)

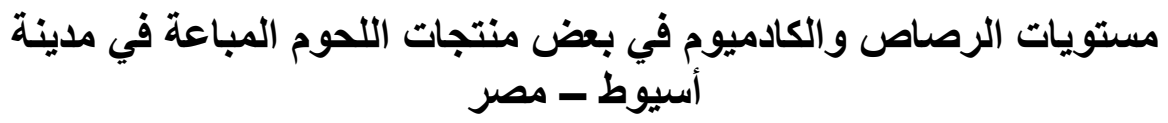

$$
\text { شريف محد سبي عبدالله ، زكريا مختار زكي }
$$

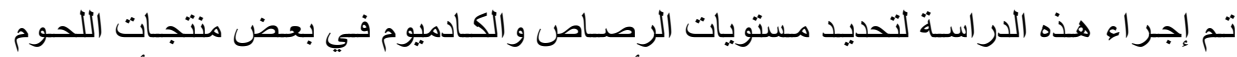

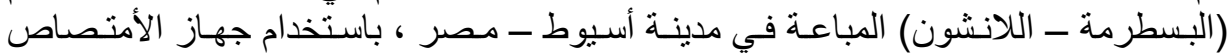

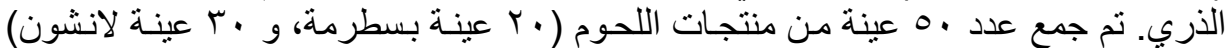

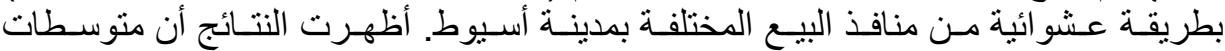

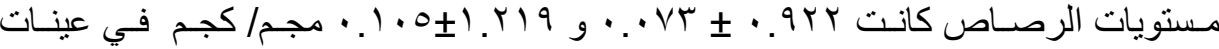

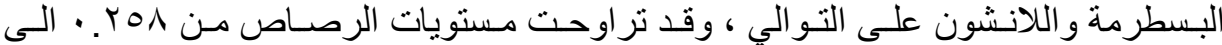

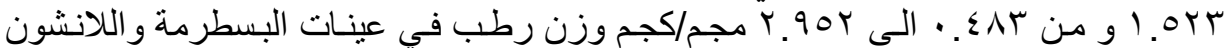

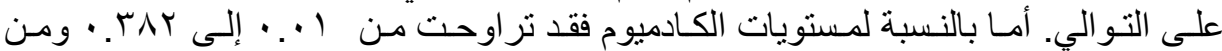

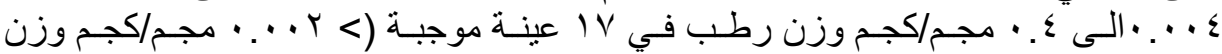

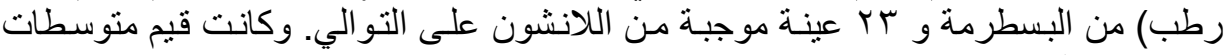

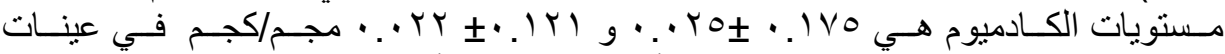

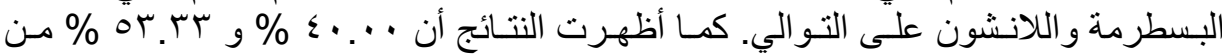

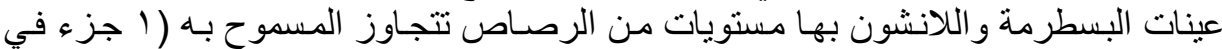

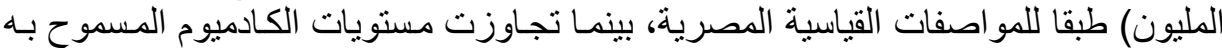

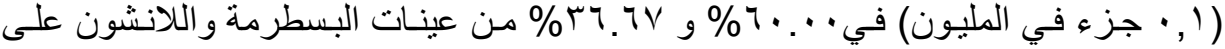

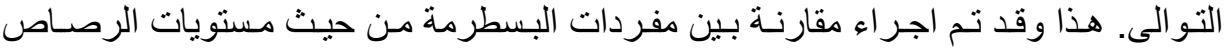

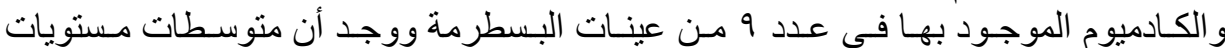

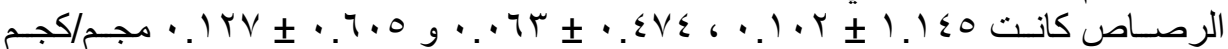

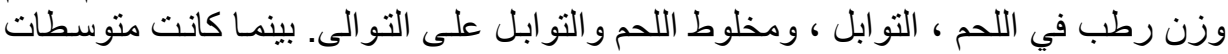

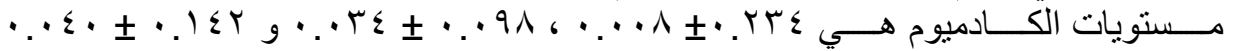

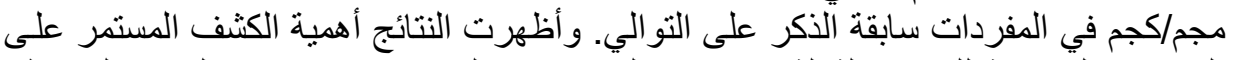

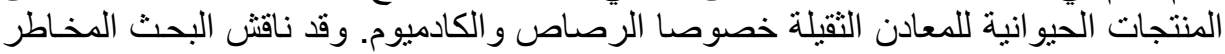

\section{SUMMARY}


In this study, the levels of lead and cadmium in a total of 50 meat products (20 of Basterma and 30 of Luncheon) samples had been assessed using Atomic Absorption Spectrophotometer. The samples were collected randomly from different retail markets in Assiut city, Egypt. The obtained results showed that the means values for lead levels were $0.922 \pm 0.073$ and $1.219 \pm 0.105 \mathrm{mg} / \mathrm{kg}$ wet weight with a range of 0.258 to 1.523 and 0.483 to $2.952 \mathrm{mg} / \mathrm{kg}$ in the examined basterma and luncheon samples, respectively. The cadmium levels ranged from 0.01 to 0.382 with a mean value of $0.175 \pm 0.025 \mathrm{mg} / \mathrm{kg}$ wet weight and from 0.004 to 0.4 with a mean value of $0.121 \pm 0.022 \mathrm{mg} / \mathrm{kg}$ wet weight in the 17 positive basterma and 23 positive luncheon samples, respectively. Of the examined basterma and luncheon samples 40.00 and $53.33 \%$ showed lead levels above the maximum permissible limits (1 ppm), respectively. Cadmium levels were above the maximum permissible limits (0.1ppm) in 60.00 and $36.67 \%$ of the examined basterma and luncheon samples, respectively. Assessment of the metals in basterma variables showed that the means values of lead levels in meat $(\mathrm{M})$, spices $(\mathrm{S})$ and mixture of both $(\mathrm{X})$ from 9 of the examined basterma samples were $1.145 \pm 0.102$, $0.474 \pm 0.063$ and $0.605 \pm 0.172 \mathrm{mg} / \mathrm{kg}$ wet weight, respectively. The Cadmium levels means values were $0.234 \pm 0.008,0.098 \pm 0.034$ and $0.142 \pm 0.04 \mathrm{mg} / \mathrm{kg}$ wet weight for the meat, spices and their mixture, respectively. A significant difference $(\mathrm{P}<0.05)$ was found between lead and cadmium levels means values of meat and either of the spices or the mixture variables. The hygienic and toxicological aspects of the detected metals had been discussed.

Key words: heavy metals, lead, cadmium, meat products, basterma, luncheon

\section{INTRODUCTION}

Meat and meat products are important for human diet because they provide a great part of nutrients. Improvements on the food production and processing technology had increased the chances of contamination of food with various environmental pollutants, especially heavy metals. Ingestion of these contaminants by animals causes deposition of residues in meat. Over the past few decades, both developed and developing countries have experienced equally life and food style changes that have led to an increased demand for processed foods. Some heavy metals get deposited in food as residues during processing. When the residues levels go beyond the prescribed 
standards, they cause deleterious effects on human health, especially when consumed continuously (Ragab and Soliman, 2009).

Contamination with heavy metals is a serious threat because of their toxicity, bioaccumulation and biomagnifications in the food chain (Iwegbue et al., 2008). These pollutants often have direct physiological toxic effects because they are stored or incorporated in tissues, sometimes permanently (Bokori et al., 1996; Mariam et al., 2004).

Metals which can be particularly harmful to animals and man include lead, cadmium, arsenic, mercury, copper, selenium and molybdenum. They are usually toxic in low amounts and are therefore a potential health hazard. These elements can accumulate in primary products that are growing satisfactorily, but still affect animals and man (Irfana et al., 2004).

In recent years, much attention has been focused on the concentrations of heavy metals in foods in order to check for those hazardous to human health (Moiseenko and Kudryavtseva, 2001; Mansour and Sidkey, 2002; Farkas et al., 2003). The edible species have been widely investigated, e.g. beef, veal, pork, camel, chicken (Boulis, 1993; Hecht and Kumpulainen, 1995; Youssef, 2009). Minerals and heavy metal contents of retail meat and meat products were also determined (Tamate, 1987; Essa, 1994; Iwegbue et al., 2008; Ragab and Soliman, 2009).

The levels of heavy metals in meat and meat products depends on factors such as environmental conditions, type of pasture and genetic characteristics of organisms. Furthermore, technological treatments are important for levels of heavy metals in meat products (Demirezen and Aksoy, 2004).

Basterma is a dry-cured meat product produced in Egypt. It is categorized as an intermediate moisture food (leistner, 1988). Its name comes from bastirma, meaning being pressed for the beef is squeezed between stones to lose its water content. Basterma was produced from whole muscle obtained from certain parts of beef and water-buffalo carcasses, but nowadays it mostly produced from frozen beef. Muscles are cleaned of tendon and fat and then cured, dried, pressed and coated with garlic, paprika, red pepper and water containing paste (cemen), and again dried. The production process of basterma takes approximately a month. Likewise, Luncheon is a widely consumed ready-to-eat meat product in Egypt. It is prepared from frozen beef with additives and filling agents. The main source of metals in meat products arises from 
contamination of animal feeds, and drinking water source and processing (Demirezen and Uruc, 2006; Iwegbue et al., 2008).

Primary contamination of meat products with heavy metals may be due to the contamination of meat itself. Secondary contamination may occur due to processing and addition of spices (Larkin et al., 1954)

The main sources of lead pollution in the environment are industrial production processes and their emissions as well as the use of paints and anti-rust agents (Gazza, 1990). Excess lead is known to reduce the cognitive development and intellectual performance in children and to increase blood pressure and cardiovascular disease incidence in adults (Commission of the European Communities, 2001).

Contamination of meat products with cadmium might occur from animals grazing on lands spread with sewage sludge or phosphate fertilizers or from animals grazing on lands contaminated with industrial cadmium effluent. Cadmium from soil could reach man through vegetables, milk and meat (Stenstrom and lonsjo, 1974). High amount of cadmium, a carcinogen, can cause kidney damage and bone demineralization (Shelle and Ayejuyo, 2011).

The purpose of this study was to determine the levels of lead and cadmium in some meat products (basterma and luncheon) collected from different retail markets in Assiut city, Egypt. As well, to compare the levels of those metals in the meat, spices paste (outer coat) and the mixture of both in some basterma samples.

\section{MATERIALS and METHODS}

\section{Samples Collection:}

A total of 50 samples (20 of basterma and 30 of luncheon) were randomly collected from different retail markets in Assiut city, Egypt. The samples were dispatched directly to the laboratory for analysis, otherwise kept frozen $\left(-18{ }^{\circ} \mathrm{C}\right)$ till analysis, after their sensory assessment.

\section{Sensory Assessment:}

Three consumer-based sensory panels were conducted to evaluate the color, flavor, consistency and overall acceptability of the basterma and luncheon samples using a 9-point hedonic scale (Peryam and Pilgrim, 1957)

\section{Lead and Cadmium Determination}

3.1. Samples Preparation: 
Nitric acid digestion was used to prepare the samples according to Hseu, 2004 with modification.

In case of basterma the outer coat (spices paste) was roughly removed. From the mixed sample 0.5 gm (wet weight) was weighed into a clean flask, previously washed with nitric acid then de-ionized water and dried, then $5 \mathrm{ml}$ of nitric acid $(68 \%)$ were added. The digestion flasks were kept overnight, and then put on the hotplate at $80^{\circ} \mathrm{C}$ until all the tissues were dissolved and the brown fumes of $\mathrm{NO}_{3}$ disappeared (the sample become clear). Then, the sample was filtered using ashless filter paper (Whatman, Cat. No. 1443 090), then diluted till $50 \mathrm{ml}$ with deionized water. A blank was prepared in the same way.

\subsection{Variables Preparation:}

Nine of the basterma samples were divided into two parts, one part was prepared as before. The other part was divided into three variables; meat from the core of the sample (M), the outer coat "spices" $(\mathrm{S})$, and a mixture of the whole sample (X). From each mixed variable, $0.5 \mathrm{~g}$ was weighed into a clean flask and treated as mentioned above. A blank was prepared in the same way.

\subsection{Standard solutions:}

The target metals (lead and cadmium) were determined against aqueous standards. Standards prepared at dilutions 0.0, 0.002, 0.004, $0.006,0.008$ and $0.01 \mathrm{ppm}$ for cadmium and 0.0, 0.02, 0.04, 0.08 and $0.1 \mathrm{ppm}$ for lead. Stock standard solutions (Merk, Germany) of each element were used to prepare calibration solutions to obtain calibration curves.

The metal analysis of samples was done in the Central Laboratory of the Faculty of the Veterinary Medicine, Assiut University using a ZEEnit $700 \mathrm{P}$ Atomic Absorption Spectrophotometer with Graphite. The contents of heavy metals were expressed as $\mathrm{mg} / \mathrm{kg}$ of the sample based on wet weight.

\section{Statistics:}

Statistical analysis was conducted with the Statistical Package for Social Science (SPSS for Windows Version 13; SPSS GmbH, Munich, Germany). Paired-Sample $\mathrm{T}$ Test and One-Way ANOVA with subsequent Duncans multiple range tests were used to determine the difference between groups. 


\section{RESULTS}

\section{Sensory Assessment:}

All the examined samples were organoleptically accepted except one luncheon sample (3.33\%) which showed undesirable appearance. Basterma samples showed light red to red-brown color, salty or weak acidic flavor and slight firm consistency. Color of luncheon samples were light pink to red, with spicy or acidic flavor, and slight firm or friable consistency.

\section{Lead and Cadmium Levels:}

The obtained results revealed that all the examined basterma and luncheon samples showed detectable levels ( $>0.002 \mathrm{mg} / \mathrm{kg}$ wet weight) of lead (Table 2). The minimum, maximum and mean values for lead levels in the examined basterma samples were $0.258,1.523$ and $0.922 \pm$ $0.073 \mathrm{mg} / \mathrm{kg}$ wet weight, respectively. As for luncheon samples, the previously mentioned values were $0.483,2.952$ and $1.219 \pm 0.105$ $\mathrm{mg} / \mathrm{kg}$, respectively. Statistical analysis with Paired-Sample T Test declared the presence of significant difference $(\mathrm{P}<0.05)$ between the means values of lead levels of both basterma and luncheon, where luncheon showed the higher mean value (Table1).

Out of the 20 examined basterma samples only 17 (85\%) showed detectable levels ( $>0.002 \mathrm{mg} / \mathrm{kg}$ wet weight) of cadmium, which ranged from 0.01 to 0.382 with a mean value of $0.175 \pm 0.025 \mathrm{mg} / \mathrm{kg}$ wet weight. As for the 30 examined luncheon samples only $24(80 \%)$ showed detectable concentrations of cadmium. One of these 24 positive samples had cadmium concentration of $7.116 \mathrm{mg} / \mathrm{kg}$ wet weight and not included in the calculations of minimum, maximum or mean and standard error values. The other 23 positive samples had a cadmium mean value of $0.121 \pm 0.022$ and a range from 0.004 to $0.400 \mathrm{mg} / \mathrm{kg}$ (Table 1 and 2). A non-significant difference $(\mathrm{P}>0.05)$ was found between the means values of cadmium levels of positive basterma and luncheon samples (Table1).

The data presented in Table 2 revealed that $8(40 \%)$ and 16 $(53.33 \%)$ samples out of the 20 basterma and 30 luncheon examined samples showed lead concentration exceeded the Egyptian standards permissible limits for lead (EOSQC, 1993) which is 1ppm, respectively.

Out of the 20 examined basterma samples, $12(60.00 \%)$ showed cadmium levels which exceed the recommended Egyptian standards permissible limits for cadmium which is $0.1 \mathrm{ppm}$ (EOSQC, 1993). As for luncheon only $11(36.67 \%)$ out of the 30 examined samples showed cadmium levels above the recommended standards (Table 2). 
Concerning basterma variables, as shown in Table 3 the minimum and maximum values for lead levels were 0.526 and 1.523; 0.231 and $0.758 ; 0.019$ and $1.293 \mathrm{mg} / \mathrm{kg}$ wet weight for meat $(\mathrm{M})$, spices (S) and their mixture (X), respectively. The means values for lead levels in the previously mentioned variables were $1.145 \pm 0.102,0.474 \pm$ 0.063 , and $0.605 \pm 0.172 \mathrm{mg} / \mathrm{kg}$, respectively.

Statistical analysis of data declared the presence of nonsignificant difference $(\mathrm{P}>0.05)$ between the means values of lead levels of the spices and the mixture variables. However, a significant difference $(\mathrm{P}<0.05)$ was found between the mean value of the meat variable and that of either the spices or the mixture variables. The meat variable recorded the highest mean value (Table 3 ).

As for cadmium levels in the basterma variables, the data recorded in Table 3 pointed out that the means cadmium values were $0.234 \pm 0.008,0.098 \pm 0.034$, and $0.142 \pm 0.040 \mathrm{mg} / \mathrm{kg}$ wet weight for the meat, the spices and the mixture variables, respectively. The minimum cadmium values were $0.190,0.003$, and $0.011 \mathrm{mg} / \mathrm{kg}$, while the maximum values were $0.263,0.222$, and $0.251 \mathrm{mg} / \mathrm{kg}$ for the meat, the spices and the mixture variables, respectively.

Using One-Way ANOVA with subsequent Duncan's multiple range tests a significant difference $(\mathrm{P}<0.05)$ was found between the mean value of the meat variable and that of either the spices or the mixture variable, where the meat variable showed the highest mean value for cadmium levels. A non-significant difference $(\mathrm{P}>0.05)$ was found between the means values of the spices and the mixture variables (Table 3).

Table 1: Statistical values for lead and cadmium levels $(\mathrm{mg} / \mathrm{kg}$ wet weight) in the examined basterma and luncheon samples

\begin{tabular}{|c|c|c|c|c|}
\hline \multirow{2}{*}{ Traits } & \multicolumn{2}{|c|}{ Lead } & \multicolumn{2}{|c|}{ Cadmium } \\
\hline & Basterma & Luncheon & Basterma* & Luncheon** \\
\hline Min & 0.258 & 0.483 & 0.010 & 0.004 \\
\hline Max & 1.523 & 2.952 & 0.382 & 0.400 \\
\hline Mean $\pm \mathrm{SE}$ & $\begin{array}{c}0.922 \pm \\
0.073^{\mathrm{a}}\end{array}$ & $\begin{array}{l}1.219 \pm \\
0.105^{\mathbf{b}}\end{array}$ & $0.175 \pm 0.025^{\mathrm{a}}$ & $0.121 \pm 0.022^{a}$ \\
\hline
\end{tabular}

$* \mathrm{n}=17$

Mean values (for each element) in the same raw with different superscript are significantly different $(\mathrm{P}<0.05)$ 
Table 2: Basterma and luncheon tested samples, positive samples (\%), samples (\%) within the permissible limits and samples (\%) exceed the permissible limits for lead and cadmium levels.

\begin{tabular}{|l|c|c|c|c|}
\hline \multirow{2}{*}{ Traits } & \multicolumn{2}{c|}{ Lead } & \multicolumn{2}{c|}{ Cadmium } \\
\cline { 2 - 5 } & Basterma & Luncheon & Basterma & Luncheon \\
\hline Samples tested & 20 & 30 & 20 & 30 \\
\hline Samples positive (\%) & $20(100 \%)$ & $30(100 \%)$ & $17(85 \%)$ & $24(80 \%)$ \\
\hline $\begin{array}{l}\text { Samples (\%) within } \\
\text { the permissible limits }\end{array}$ & $12(60.00 \%)$ & $14(46.67 \%)$ & $8(40.00 \%)$ & $19(63.33 \%)$ \\
\hline $\begin{array}{l}\text { Samples (\%) exceed } \\
\text { the permissible limits }\end{array}$ & $8(40.00 \%)$ & $16(53.33 \%)$ & $12(60.00 \%)$ & $11(36.67 \%)$ \\
\hline Permissible limits & \multicolumn{2}{|c|}{$1 \mathrm{ppm}$} & \multicolumn{2}{c|}{$0.1 \mathrm{ppm}$} \\
\hline
\end{tabular}

* = one sample showed cadmium concentration of 7.116 and not included in the calculations of Min., Max., or Mean and standard error (SE) values.

Table 3: Statistical values for lead and cadmium levels $(\mathrm{mg} / \mathrm{kg}$ wet weight) in variables of nine of the examined basterma samples

\begin{tabular}{|l|c|c|c|c|c|c|}
\hline \multirow{2}{*}{ Traits } & \multicolumn{3}{|c|}{ Lead } & \multicolumn{3}{c|}{ Cadmium } \\
\cline { 2 - 7 } & $\mathrm{M}$ & $\mathrm{S}$ & $\mathrm{X}$ & $\mathrm{M}$ & $\mathrm{S}$ & $\mathrm{X}$ \\
\hline Min & 0.526 & 0.231 & 0.019 & 0.190 & 0.003 & 0.011 \\
\hline Max & 1.523 & 0.758 & 1.293 & 0.263 & 0.222 & 0.251 \\
\hline Mean $\pm \mathrm{SE}$ & $\begin{array}{c}1.145^{*} \pm \\
0.102^{\mathbf{a}}\end{array}$ & $\begin{array}{c}0.474 \pm \\
0.063^{\mathbf{b}}\end{array}$ & $\begin{array}{c}0.605 \pm \\
0.172^{\mathbf{b}}\end{array}$ & $\begin{array}{c}0.234 \pm \\
0.008^{\mathbf{a}}\end{array}$ & $\begin{array}{c}0.098 \pm \\
0.034^{\mathbf{b}}\end{array}$ & $\begin{array}{c}0.142 \pm \\
0.040^{\mathbf{b}}\end{array}$ \\
\hline
\end{tabular}

Mean values (for each element) in the same raw with different superscript are significantly different $(\mathrm{P}<0.05)$
$\mathrm{M}=$ meat
$\mathrm{S}=$ spices
$\mathrm{X}=$ mixture of both 


\section{DISCUSSION}

Pollution of food with heavy metals is a serious problem, which is recognized in most countries of the world (Abou-Arab, 2001; Demirezen and Uruc, 2006; Iwegbue et al., 2008; Ragab and Soliman, 2009; Nor Hasyimah et al., 2011; Shelle and Ayejuyo, 2011)

Heavy metals are metals which have a high atomic mass, including, for example, cadmium, lead, mercury and arsenic. They are usually toxic in low amounts and are therefore a potential health hazard. Metals can occur in a variety of foodstuffs of plant and animal origin. Mostly, they arise indirectly in foodstuffs from the environment. Once they become incorporated into the food they can not be removed. Control of the raw material is therefore the only mechanism for ensuring that levels do not become unsafe (Irfana et al., 2004).

Sensory assessment of the samples revealed that presence of cadmium and lead have no effect on the organoleptic properties of the meat products. The organoleptically unacceptable sample had lead $(0.528 \mathrm{mg} / \mathrm{kg})$ and cadmium $(0.040 \mathrm{mg} / \mathrm{kg})$ concentration below the maximum permissible limits which are 1 and $0.1 \mathrm{ppm}$ for lead and cadmium, respectively (EOSQC, 1993)

Lead is known to induce reduced cognitive development and intellectual performance in children and increased blood pressure and cardiovascular disease in adults. It is also associated with cancer and infertility. Lead could cause adverse effects on the renal and nervous systems and cross the placental barrier and having potential toxic effects on the fetus (Tuormaa, 1995; Pueschel et al., 1996; Commission of the European Communities, 2001; WHO, 2003)

The obtained result of lead levels in the present study was higher than those recorded by Demirezen and Uruc (2006) for basterma samples from Kayseri - Turkey, that was $12.6 \pm 0.04 \mu \mathrm{g} / 100 \mathrm{~g}$ wet weight. Likewise, Falandysz (1991); Zantopoulos et al. (1992); Khan et al. (1995); Ragab and Soliman (2009) detected lower values of lead levels in a variety of meat and meat products.

Abou-Arab (2001) found lead in different types of meat and meat products in concentration ranges of $0.010-0.061 \mathrm{mg} / \mathrm{kg}$ which are lower than the current results.

Ragab and Soliman (2009) reported nearly similar means values of lead levels in a variety of meat products (ready-to-eat) from street vendors in Alexandria Governorate - Egypt. 
Mariam et al. (2004) reported higher means levels for lead which are 2.18 and $4.25 \mathrm{mg} / \mathrm{kg}$ in beef and mutton, respectively.

In accordance with the $1 \mathrm{ppm}$ permissible limits for lead (EOSQC, 1993) 40.00 and $53.33 \%$ of the examined basterma and luncheon samples showed lead concentrations exceed these limits, respectively.

The previously mentioned result disagree with those reported by Demirezen and Uruc (2006) for a variety of meat products including basterma from Kayseri - Turkey, and by Ragab and Soliman (2009) for a variety of ready-to-eat meat products from restaurants in Alexandria Egypt, who reported that lead concentrations in all the examined samples were within the permissible limits.

Ragab and Soliman (2009) illustrated that lead concentrations in all the examined ready-to-eat meat products from street vendors in Alexandria - Egypt were above the permissible limits of $1 \mathrm{ppm}$. This is not in harmony with the current obtained results.

It was reported that the lead means concentrations values of lean beef, buffaloes' meat and imported frozen meat were lower than the permissible limit of 1 ppm (Aranha et al., 1994; Essa, 1994; Youssef, 2009). On the other hand, Boulis (1993) illustrated that the means lead concentrations values of lean buffaloes' meat, camels' meat, beef, mutton and goats' meat ranged from 3.960 to $5.648 \mu \mathrm{g} / \mathrm{g}$ wet weight which are higher than the permissible limits.

Shelle and Ayejuyo (2011) reported that the lead concentrations in the entrails (liver, stomach, intestine, colon and kidney) of cow, sheep and goat from Nigeria were ranged from $6.116-21.614 \mathrm{mg} / \mathrm{kg}$ wet weight which is greatly exceeding the recommended standards.

Cadmium may accumulate in the human body and may induce kidney dysfunction, skeletal damage and reproductive deficiencies (Commission of the European Communities, 2001). Hecht (1983) stated that cadmium concentrations in meat increase with the age of the animal and depends on the concentrations of cadmium in the feed.

The mean value for cadmium levels in the present study was higher than those recorded by Demirezen and Uruc (2006) who found that the mean value of cadmium in basterma samples from Kayseri Turkey was $0.78 \pm 0.04 \mu \mathrm{g} / 100 \mathrm{~g}$ wet weight.

Ragab and Soliman (2009) reported lower levels of cadmium in a variety of meat products (ready-to-eat) from restaurants in Alexandria Governorate - Egypt. However they reported a nearly similar cadmium levels in the ready-to-eat products from street vendors. As well 
Gonzalez-Weller et al. (2006) reported lower cadmium means values of $1.90 \mu \mathrm{g} / \mathrm{kg}$ in beef, and $4.76 \mu \mathrm{g} / \mathrm{kg}$ in meat products of beef in Teneriffe Island, Spain.

Lower cadmium concentrations were recorded by Vos et al. (1987); Jorhem et al. (1991); Essa (1994); Demirezen and Uruc (2006); Youssef (2009) in different types of meat and meat products. However Boulis (1993) detected higher levels of cadmium in buffaloes' meat, camels' meat and beef. Likewise, higher levels of cadmium $(0.33 \mathrm{mg} / \mathrm{kg}$ for lean beef and $0.37 \mathrm{mg} / \mathrm{kg}$ for lean mutton) were detected by Mariam et al. (2004).

Of the examined basterma and luncheon samples 60.00 and $36.67 \%$ of the samples showed cadmium levels which exceed $0.1 \mathrm{ppm}$ permissible limits (EOSQC, 1993), respectively.

The previous results differed from those illustrated by Demirezen and Uruc (2006) for a variety of meat products including basterma from Kayseri - Turkey, and by Ragab and Soliman (2009) for a variety of ready-to-eat meat products from restaurants in Alexandria - Egypt, who reported that cadmium levels in all the examined samples were below the recommended standards. However, Ragab and Soliman (2009) mentioned that cadmium levels in all examined ready-to-eat meat products from street vendors in Alexandria - Egypt were above the permissible limits which seems higher than the current results.

Boulis (1993) illustrated that the means cadmium concentrations values of lean buffaloes' meat, camels' meat, beef, mutton and goats' meat ranged from 0.2965 to $0.4041 \mu \mathrm{g} / \mathrm{g}$ wet weight which are higher than the permissible limit of 0.1ppm. however, Youssef (2009); Essa (1994) reported that the cadmium means concentrations values of lean beef, buffaloes' meat and imported frozen meat was lower than the permissible limit of $0.1 \mathrm{ppm}$.

Shelle and Ayejuyo (2011) found that the cadmium concentrations in the entrails (liver, stomach, intestine, colon and kidney) of cow, sheep and goats from Nigeria ranged from $0.764-$ $16.114 \mathrm{mg} / \mathrm{kg}$ wet weight which is far exceeding the permissible limits.

The obtained results for lead and cadmium levels in basterma variables indicated that the highest concentrations for both of them were in the meat variable which suggested that meat (raw material) may be the main source of these heavy metals in the meat products. This is in agreement with that mentioned by Larkin et al. (1954), who reported that primary contamination of meat products with heavy metals may be due to the contamination of meat itself. 
Boulis (1993) reported high concentrations of lead and cadmium, exceeded the Egyptian standards permissible limits, in lean buffaloes' meat, camels' meat, beef, mutton and goats' meat.

As well Ragab and soliman (2009) reported that contamination of food by heavy metals may come from utensils, raw materials, or transport methods used and may also occur due to the lack of appropriate storage facilities.

Reviewing all data in the present study indicated that levels of cadmium in basterma samples was higher than in luncheon samples, however, lead concentrations were higher in luncheon than in basterma samples. This may be attributed to inclusion of spices in the substance of luncheon more than in that of basterma.

Larkin et al. (1954) mentioned that secondary contamination of meat products may occur due to processing and addition of spices, like pepper which contains higher levels of lead $(>2.5 \mathrm{ppm})$. Likely, Abou Arab (2001) reported that the lead content of sausage was higher than that of meat used for its production, presumably due to the spices used in sausage production.

In conclusion the current study revealed that lead and cadmium levels exceeded the Egyptian standards permissible limits in considerable percentage for the examined basterma and luncheon samples. As well the study indicated that the concentrations of cadmium and lead were higher in meat of basterma than in the spices. Hence, better selection of the raw material, including an analysis for toxic heavy metals prior to processing, could surely improve the situation. As well, better product may be obtained by more careful handling practices and processing of raw materials.

\section{REFERENCES}

Abou-Arab, A.A.K. (2001): Heavy metal contents in Egyptian meat and the role of detergent washing on their levels. Food and Chemical Toxicology, 39: 593-599.

Aranha, S.; Nishikawa, A.M.; Taka, T. and Salioni, E.M.C. (1994): Cadmium and lead levels in bovine livers and kidneys in Brazil. Revista-do-Instituto-Adolf Lutz, 54: 16-20.

Bokori, J.; Fekete, S.; Glavit, R.; Kaday, I.; Konez, J. and Kovari, L. (1996): Complex study of the physiological role of cadmium IV. Effects of prolonged dietary exposure of broiler chickens to cadmium. Acta Veterinaria Hungarica, 44: 57-74. 
Boulis, W.A. (1993): Some Trace Elements in Tissues of Animals slaughtered in Assiut Province. M.V.Sc. Thesis (Meat Hygiene), Fac. Vet. Med., Assiut University.

Commission of the European Communities (2001): Commission Regulation (EC) No. 221/2002 of 6 February 2002 amending regulation (EC) No. 466/2002 setting maximum levels for certain contaminants in foodstuffs. Official Journal of the European Communities, Brussels, 6 February 2002.

Demirezen, D. and Aksoy, A. (2004): Accumulation of heavy metals in Typha angustifolia (L.) and Potamogeton pectinatus (L.) living in Sultan Marsh (Kayseri, Turkey). Chemoshere, 56: 685-696.

Demirezen, D. and Uruc, K. (2006): Comparative study of trace elements in certain fish, meat and meat products. Meat Science, 74: 255-260.

EOSQC "Egyptian Organization for Standrization and Quality Control" (1993): Maximum level for heavy metal contamination in food. ESN2360.

Essa, H.H. (1994): Determination of Some Trace Elements in Imported Fish and Meat. M. V. Sc. Thesis (Meat Hygiene), Fac. Vet. Med., Assiut University.

Falandysz, J. (1991): Manganese, copper, zinc, iron, cadmium, mercury and lead in muscle meat, liver and kidneys of poultry, rabbit and sheep slaughtered in the northern part of Poland, 1987. Food Additives and Contaminants, 8 (1): 71-83.

Farkas, A.; Sala'nki, J. and Speczia'r, A. (2003): Age and size-specific patterns of heavy metals in the organs of fresh water fish Abramis brama L. populating a low-contaminated site. Water Research, 37: 959-964.

Gazza, F. (1990): Lead and cadmium: Sources, metabolism, dangers and presence in Meat and Meat products. Ann. Della Facolta di Med. Vet., 10: 171-181.

Gonzalez-Weller, D.; Karisson, L.; Caballero, A.; Hernadez, F.; Gutierrez, A.; Gonzelex-Iglesias, T.; Marino, M. and Hardission, $A$ (2006): Lead and cadmium in meat and meat products consumed by the population in Tenerife Island, Spain. Food Add. Cont., 23: 757-763.

Hecht, H. (1983): Toxische scwermetalle in fleish und innerein verschiedener tierarten. Fleischwitschaft, 63: 544-558. 
Hecht, H. and Kumpulainen, J. (1995): Essential and toxic elements in meat and eggs. Mitteilungsblattder Bundesantalt fur Fleishforschung Kulmbach, 34 (127): 46-52.

Hseu, Z-Y. (2004): Evaluating heavy metal contents in nine composts using four digestion methods. Bioresource Technology, 95: 53-59.

Irfana, Mariami, Shehla, I. and Saeed, A.N. (2004): Distribution of some trace and macrominerals in beef, mutton and poultry. Int. J. Agri. Biolg., 6 (5): 816-820.

Iwegbue, C.M.A.; Nwajei, G.E. and Iyoha, E.H. (2008): Heavy metal residues of chicken meat and gizzard and turkey meat consumed in southern Nigeria. Bulgarian J. Vet. Med., 11(4): 275-280.

Jorhem, L.; Siorach, S.; Sundstrom, B. and Ohlin, B. (1991): Lead, cadmium, arsenic and mercury in meat, liver and kidney of Swedish pigs and cattle in 1984 - 1988. Food Additives and Contaminants, 8: 201-212.

Khan, T.A.; Diffay, C.B.; Forester, M.D.; Thompson, J.S. and Mielke, W.H. (1995): Trace element concentrations in tissues of goats from Alabama. Vet. Human Tox., 37: 327-329.

Larkin, D.; Margaret, P.; Bartlet, J.C. and Chapman, R.A. (1954): The lead, zinc and copper content of foods. Food Res., 19: 211-218.

Leistner, L. (1988): Shelf-stable products and intermediate moisture foods based on meat. In Water Activity: Theory and Applications to Food, Rockland, L. B. and Bouchat, L. R. (Eds.) pp. 295-237. New York, Marcel Dekker, Inc.

Mansour, S.A. and Sidky, M.M. (2002): Ecotoxocological Studies. 3. Heavy metals contaminating water and fish from Fayoum Governorate, Egypt. Food Chemistry, 78: 15-22.

Mariam, I.; Iqbal, S. and Nagra, S.A. (2004): Distribution of some trace and macro minerals in beef, mutton and poultry. Int. J. Agri. Biology, 6: 816-820.

Moiseenko, T.I. and Kudryavtseva, L.P. (2001): Trace metal accumulation and fish pathologies in areas affected by mining and metallurgical enterprises in the Kola Region. Russian Environ. Pollution, 114: 285-297.

Nor Hasyimah, A.K.; James Noik, V.; Teh, Y.Y.; Lee, C.Y. and Pearline Ng, H.C. (2011): Assessment of cadmium $(\mathrm{Cd})$ and Lead $(\mathrm{Pb})$ levels in commercial marine fish organs between wet markets and supermarkets in Klang Vally, Malaysia. Int. Food Research J., 18: 770-777. 
Peryam, D.R. and Pilgrim, P.J. (1957): Hedonic scale method for measuring food perefrences. Food Tech., 11: 9-14.

Pueschel, S.M.; Linakis, J.G. and Anderson, A.C. (1996): Lead poisoning in childhood. Paul, H. (Ed). Brooks Publishing.

Ragab, Mervate, K.I. and Soliman, Nabila, F. (2009): Some heavy metal residues in fast foods (Ready-to-eat) collected from Alexandria Governorate. Mansoura Vet. Med. J., XI (2): 147-161.

Shelle, R.O.D. and Ayejuyo, O.A. (2011): Determination of heavy metals in ready to eat entrails. Internet J. Food Safety, 13: 16-19.

Stenstrom, T. and Lonsjo, H. (1974): Cadmium availability to wheat: A study with radioactive tracers under field conditions. Ambio, 3: 87-90.

Tamate, R. (1987): Distribution, content and variation of minerals in meat and meat products. Japanese, J. Dairy and Food Sci., 36: A1.

Tuormaa, T.E. (1995): The role of chromium, selenium and copper in human and animal metabolism. J. Orthomol. Med., 10: 149-164.

Vos, G.; Hovens, J.P.C. and Delft, W.V. (1987): Arsenic, cadmium, leads and mercury in meat, livers and kidneys of cattle slaughtered in The Netherlands during 1980-1985. Food Additives and Contaminants, 4: 73-88.

WHO (2003): Elemental mercury and inorganic mercury compounds: Human health aspects. Concise International Chemical Assessment Document 50. World Health organization, Geneva.

Youssef, T.H. (2009): Levels of Some Heavy Metals in Slaughtered Animals tissues. M.V.Sc. Thesis (Meat Hygiene), Fac. Vet. Med., Assiut University.

Zantopoulos, N.; Antoniou, V. and Tsoukali, H. (1992): Lead concentrations in plants and animal tissues. J. Environ. Sci. Health, 6: 1453-1458. 